\title{
DEVELOPING POSITIVE EDUCATION INTEGRATED EXTENSIVE READING MATERIALS FOR EFL STUDENTS
}

\author{
Andini Linarsih \\ Universitas Tanjungpura Pontianak \\ Corresponding Email: andinilinarsih@untan.ac.id
}

Received: $5^{\text {th }}$ of September 2020, Accepted: $19^{\text {th }}$ of October 2020, Published: $4^{\text {th }}$ of December 2020

\begin{abstract}
Positive education for students has an impact on improving wellbeing. The cultivation of positive educational values can be integrated into all learning activities, especially reading activities. This study aims to make the extensive reading text as supplementary material in English courses that contain positive educational values for the readers. It is hoped that after reading the text in this book, the readers will not only improve their English skills but also have a psychological effect that can motivate students to love learning and be persistent in learning in general, learning English in particular. Primary data obtained in this study were obtained directly from respondents, in the form of exploratory results carried out in preliminary studies carried out through discussions with experts related to content and language, as well as data on limited trial results on 1stsemester students at a university in Pontianak. The data collection instrument was a questionnaire instrument. This study uses the Research and Development approach developed by Doolitle (2015). The results of the validation from the content validator, the language validator, and the students showed that the book was suitable for use even though it had to go through several revisions.
\end{abstract}

Keywords: Positive Education, Extensive Reading, wellbeing.

\begin{abstract}
Abstrak
Pendidikan positif bagi pelajar berpengaruh terhadap perkembangan wellbeing. Penanaman nilai-nilai pendidikan yang positif dapat diintegrasikan ke dalam semua kegiatan pembelajaran khususnya kegiatan membaca. Penelitian ini bertujuan untuk menjadikan teks bacaan ekstensif sebagai materi tambahan dalam kursus bahasa Inggris yang mengandung nilai edukatif positif bagi pembacanya. Diharapkan setelah membaca teks dalam buku ini, para pembaca tidak hanya meningkatkan kemampuan bahasa Inggrisnya tetapi juga memiliki efek psikologis yang dapat memotivasi siswa untuk senang belajar dan gigih dalam belajar pada umumnya, khususnya belajar bahasa Inggris. Data primer yang diperoleh dalam penelitian ini diperoleh langsung dari responden, berupa hasil eksplorasi yang dilakukan pada studi pendahuluan yang dilakukan melalui diskusi dengan pakar terkait konten dan bahasa, serta data hasil uji coba terbatas pada mahasiswa semester 1 di universitas di Pontianak. Instrumen pengumpulan data adalah instrumen angket. Penelitian ini menggunakan pendekatan Research and Development yang dikembangkan oleh Doolitle (2015). Hasil validasi dari validator isi, validator bahasa, dan siswa menunjukkan bahwa buku tersebut layak digunakan meskipun harus melalui beberapa kali revisi.
\end{abstract}

Kata kunci: Pendidikan Positif, Membaca Ekstensif, kesejahteraan.

Copyright (c) 2020 Andini Linarsih

e-ISSN: 2089-2810

p-ISSN: 2407-151X

(c) (1)( () 


\section{INTRODUCTION}

The adaptation process from high school students to higher education students is a complex process. In this period of transition to their adult years, they are required to form, pursue, and set their own goals which have broad implications for their success and welfare, including in the university context (Kift, 2009). For this reason, students'readiness in facing that phase is required. If they are successful in facing the adaptation phase, they will get good learning results. Conversely, if it does not work, freshmen will be vulnerable to stress, anxiety, and mental health problems (Stallman, 2010). Casey (2013) states that first-year students aged 18-20 years tend to experience high stress levels and low wellbeing easily compared to older people. A study conducted by Sarina (2012) on 122 first-year students at the University of Indonesia stated that there was a negative and significant relationship between the stress levels experienced by students and their psychological wellbeing. The more stressed they are on their academic life, the lower the psychological wellbeing condition of a person is. A study conducted by Rizki \& Listiara, (2015) on students at a university in Semarang revealed that an effective adaptation process will affect the student's school-wellbeing. The low wellbeing condition of a person will lead to low student resilience in facing problems. This will have an impact on cases such as high student drop-out rates, depression and even student suicide rates. For this reason, universities need to assist students, especially first-year students, to adapt well in academic life. The Law of the Republic of Indonesia on Higher Education (2012) states that universities are places for students, as members of community groups, to develop their potential. The 2003 National Education System Law and PP no. 17 of 2010 actually requires every learning activity on and off campus. Therefore, universities are expected to develop a learning process that foster effective adaptation process in order to have a positive impact on student learning outcomes and development of self-potential. All courses should also promote positive values in their learning. It is hoped that positive education can foster students' intrinsic motivation to do self-directed learning for students with low learning motivation, enthusiasm and participation in the classroom learning (Agung, 2019).

In English language learning in university lack of mastery of English vocabulary is still the main issue of understanding English materials (Mumary Songbatumis, 2017). This is a paradox as many free English learning platform ranging from Podcasts, Youtube channels, Forums, and learning sites such as VOA Learning English, BBC Learning English in internet that may facilitate students to improve their vocabulary by themselves. Thus, teachers need to facilitate students by giving a 
particular task that not only improve students' English vocabulary skills but also increase students' positive encouragement that may encourage them to do self-directed learning in the future. One form of activity suggested is an extensive one with material on inspirational figures of West Kalimantan. The stories of these great figures are expected to be a source of inspiration for students' learning, considering that these figures may have similar conditions and life stories with students. This study will shed the light on two issues namely:

1. Can extensive reading sources in the form of texts about biographies of famous people in West Kalimantan introduce positive educational values for English students?

2. What kinds of activities after reading English can introduce positive education values to students in tertiary institutions

This research aims to develop an Extensive Reading resource text model that promotes positive educational values for students in tertiary institutions, especially for students from non-English study programs.

A. Extensive reading as An alternative language learning

Extensive Reading is a form of reading instruction in large numbers. According to Day and Bamford (2002) Extensive Reading, also known as 'Reading for Pleasure', has ten (10) demands in its implementation, namely:

1. The reading material is easy.

The reading material must be following the competence of the student so that it is easily understood by the student.

2. A Variety of reading material on a wide range of topics must be available.

The availability of various types of reading material on various topics.

3. Learners choose what they want to read.

Students choose the literature they want to read by themselves.

4. Learners read as much as possible.

Students read as much as possible.

5. The purpose of reading is usually related to pleasure, information, and general understanding. The purpose of reading is for pleasure, to get information, and to gain understanding in general.

6. Reading is own its reward.

Reading success depends on the standards set by readers.

7. Reading speed is usually faster rather than slower. 
Read speeds are usually faster than slower.

8. Reading is individual and silent.

Reading is individual and silent.

9. Teacher orient and guide their students.

The teacher is in charge of providing views and guidance to students.

10. The teacher is a role model of a reader.

The teacher is a role model for students so that the teacher must be someone who also has reading habits as well.

Of the ten principles above, there are only two (2) principles that form the basis of extensive reading instruction, namely the availability of various reading topics and students reading as much as possible. Until now, there are extensive reading materials in large numbers and easy to access by students online via electronic books and extensive reading websites that can be accessed for free or paid. One of the extensive reading websites that can be accessed for free is er.central.com. Almost all of the reading material is about the target language culture.

Currently, there is a shift in the learning paradigm from positivism to post-positivism. According to Jacobs \& Renandya, (2014) post-positivism puts students into people who take full control of existing learning. So far, extensive reading activities are top-down, that is, they come from teachers. In post-positivism, the learning decisions come from the down top, namely from the students. Learning success is seen from the feelings and attitudes of students towards the selected activities. Students can choose material, activities, topics they like. Students' voices take into account. So every teacher needs to consider and even conduct a survey before deciding what activities they want to do.

Of the ten principles above, there are only two (2) principles that form the basis of extensive reading instruction, namely the availability of various reading topics and students reading as much as possible. Until now, there are extensive reading materials in large numbers and easy to access by students online via electronic books and extensive reading websites that can be accessed for free or paid. One of the extensive reading websites that can be accessed for free is er.central.com. Almost all of the reading material is about the target language culture.

Currently, there is a shift in the learning paradigm from positivism to post-positivism. According to Jacobs \& Renandya, (2014) post-positivism puts students into people who take full control of existing learning. So far, extensive reading activities are top-down, that is, they come from 
teachers. In post-positivism, the learning decisions come from the down top, namely from the students. Learning success is seen from the feelings and attitudes of students towards the selected activities. Students can choose material, activities, topics they like. Students' voices take into account. So every teacher needs to consider and even conduct a survey before deciding what activities they want to do.

There have been many studies on the success of Extensive Reading (ER) in improving the cognitive abilities of second language learners such as improving second language reading skills (Ferdila, 2014; McLean \& Rouault, 2017; Yamashita, 2008; Yoshizawa et al., 2002), improving vocabulary ( Chun et al., 2012; Green, 2020; Guo, 2012; Song, 2016), improve speaking skills (Guo, 2012; Wojtowicz, 2017), and writing skills (Kirin, 2010; Mermelstein, 2014) ((Mason and Krashen, 1997; Kirin, 2010; Mermelstein, 2015). One of the positive effects of extensive reading that is beyond the improvement of language competence is the emotional social aspect as quoted from www.erfoundation.org, which causes' confidence, motivation, enjoyment and reduce anxiety in langue learning '((Foundation, 2011). This of course makes the extensive reading program a solution to learning English for students who lack learning motivation.

So far, studies on the emotional aspects that have just been researched are still about positive attitudes and motivation towards ER activities (Ro, 2013, 2016; Ro \& Chen, 2014; Yamashita, 2013). Not much has been explored regarding the activities or topics that drive this value. This condition inspired the writer to see the potential of the contents of the ER text in arousing the socio-emotional side of readers of extensive reading material considering that every story always carries a moral message in it. How the existing moral messages can be processed in a real way and internalized emotionally by the readers. According to Krashen (1985), negative emotions provide an "affective filter" which will hinder students from understanding the given input. negative emotions will reduce student interest and motivation to continue learning. On the other hand, positive emotions can foster motivation and persistence to continue learning. Cultivating positive emotions can be through personal experience or learning from the experiences of others. The struggles of characters in famous novels in Indonesia such as Andrea Hirata in the novel Laskar Pelangi, Raditya Dika in the book and film Kambing Jantan, the story of the students from the Gontor Islamic boarding school who are successfully told in the novel Negeri 5 Menara have inspired many Indonesian children to enthusiastically achieve their dreams. These literary works provide positive waves to strengthen the dimension of resilience for society, especially the younger 
generation who watch or read them. The strong influence of literature on the emotions of readers is described by Oatley (1995) as a fictional simulation that runs in people's minds. For them to be successful, readers (a) adopt character goals and use their planning procedures to connect actions in meaningful ways, (b) form mental models of the world's imagination, (c) accept speech acts addressed to them by the author, and (d) integrate different elements to create a unified experience. In providing material for these functions, great writers allow readers to respond creatively, feel emotionally moved, understand within themselves some of the relationships between actions and emotions, and sometimes experience cognitive changes.

\section{Positive Education in EFL Learning}

Each variable of the learners, especially affective factors and motivation to learn a language, has been the main subject in research on second language acquisition during the last four decades (Dörnyei, 2009). As a result, it is currently believed that learning a new language involves negotiating and re-shaping one's self-image where learning activities can on the one hand trigger anxiety (HORWITZ, Horwitz, \& Cope, 1986) and threaten the student's ego while on the other hand can get pleasure ( (Dewaele \& MacIntyre, 2014) Therefore, second language pedagogy suggests that learning a second language should create a supportive environment, students do not feel afraid of making mistakes, have good cooperation with peers and can share personal things (Brown, 2007). Furthermore, the latest construction regarding the motivation to learn a second language has developed in many ways, for example, the inclusion of self-realization, selfdevelopment, and affiliation variables (Palmieri, 2017). Through the learning process, it is hoped that students can learn from their learning environment the importance of self-realization, personal development. and affiliations Learning tanning and the relevance of learning materials should consider the background, cognitive level, and student competence are the basic principles of flow from positive psychology (Csikszentmihalyi, 1990). Flow is a component of wellbeing which consists of positive emotions, involvement, relationships, meaning, delivery, and physical wellbeing and empathy. Flow is an improved form of construction developed by the South Australian Health \& Medical Research Institute. (SAHMRI) collaborated with Seligman as a scientist who presented the PERMA concept.

The following is the PERMA concept quoted from the www.positivepsychology.com page:

P - Positive Emotions: Fostering an attitude of optimism and positive thinking

E - Engagement: Providing life experiences 
R - Relationships: Cultivate strong relationships for example between students, between students and parents

M - Meaning: Students find the meaning of every activity they do. Religion and spirituality of a person can usually shape students in finding the meaning of each Step or activity that someone does.

A - Accomplishment: Having goals and ambitions in life that you want to achieve.

Empathy: empathy for events that happen to other people.

This study focuses on the promotion of positive emotional values experienced by the characters in the story to be developed. The positive emotions that will be explored in these characters are: 1. Wisdom (wisdom) which has characteristics such as creativity (creativity), curiosity (curiosity), judgment (assessment), love of learning (like to learn), and perspective.

2. Courage which has characteristics such as bravery (courage), perseverance (persistence), honesty (honesty), zest (spirit)

3. Humanity has characteristics such as love (love), kindness (kindness), social intelligence (social intelligence)

4. Justice, which has characteristics such as teamwork, fairness, leadership

5. Temperance which has characteristics such as forgiveness (forgiveness), humility (humility), prudence (justice), self-regulation (self-regulating)

6. Transcendence has characteristics such as appreciation of beauty \& excellence (appreciating beauty and perfection), gratitude (gratitude), hope (hope), humor (humor), spirituality (spirituality)

\section{METHOD}

This research is development research using the Research and Development $(\mathrm{RnD})$ method using the ADDIE model - Analysis, Design, Development, Implementation, and Evaluation. This model was chosen based on the consideration that this model is a simple model, $\mathrm{d}$ flexible and dynamic because it can be used online and offline (Allen, 2017). The product developed in this study is an extensive reading textbook. In this study, the author will only focus on the first three phases, namely the analysis stage - the development stage due to limited funds and time, while the next two phases, namely implementation, and evaluation will be carried out after the book has been completed. The results of this research will be in the form of a prototype or sample text model along with activities after reading. 
The stages of the material development model based on ADDIE based on Doolitle (2015) are: Analysis

Analysis of the appropriate text genre can make students read

Design

Compiling text along with post-reading activities that encourage students to learn about the positive education it contains.

Development

includes the extensive reading text validation phase that has been made to material expert validators, linguist validators, and expert validators as well as small scale trials. Furthermore, revisions will be made to improve the text from various aspects. This validation and trial aim to control the content of teaching materials so that they meet the needs and characteristics of students. Implementation

Trying out extensive reading materials in the limited population and distributing response questionnaires from 20 first-semester students for Universitas Tanjungpura.

Evaluation

Evaluating conditions that have not been achieved during learning

\section{FINDINGS AND DISCUSSIONS}

The Extensive Reading textbook product developed in this study has undergone several trials and improvements. Improvements were made based on input and suggestions from a content expert in content validation test, educators, in this case, reading lecturers at several universities, students in small group trials, and input from interviews with various 1st-semester students from various study programs in Tanjungpura University to perfect the Reading textbook which promotes these positive values of Education. So that later it is really capable and worthy of use in the learning process.

1. Review results from content experts:

Expert advice (psychologist):

'In general, the content has described positive values but the values of education have not been described. For example, how to apply the values of courage, wisdom, etc. in the context of learning. We can conclude that the message conveyed is more positive about life in general. questions can be added. In the aspect of wisdom, take the love of learning. In the story, it leads to that ... so the answer is the love of learning. For the aspect of wisdom, take the point of perseverance '. 
From the comments given, suggestions from expert states that the product of the Extensive Reading book that has been developed contains positive psychological values as a theoretical basis for the development of this book. Besides, content experts also suggested that each sub-section should be more detailed so that students could focus more on every aspect of positive education that was aimed at. Content experts also suggest adding questions that make readers reflect the educational value contained in the story into their English learning.

\section{Tabel 1}

Language Validation

\begin{tabular}{|c|c|c|c|c|}
\hline INDICATORS & ITEM & $\begin{array}{l}\text { Total } \\
\text { Score }\end{array}$ & $\begin{array}{l}\text { Maximum } \\
\text { Score }\end{array}$ & $\%$ \\
\hline \multirow[t]{3}{*}{ A. Simple } & 1. Accuracy & 10 & 12 & 83 \\
\hline & 2. Effectivity & 9 & 12 & 75 \\
\hline & $\begin{array}{l}\text { 3. Rigorness of the } \\
\text { term }\end{array}$ & 10 & 12 & 83 \\
\hline B. Communicative & $\begin{array}{l}\text { 4. Understanding of } \\
\text { Message or } \\
\text { Information }\end{array}$ & 10 & 12 & 83 \\
\hline C. Interactive & $\begin{array}{l}\text { 5. Ability to motivate } \\
\text { the readers }\end{array}$ & 12 & 12 & 100 \\
\hline \multirow[t]{2}{*}{$\begin{array}{l}\text { D. adjustable to } \\
\text { learners }\end{array}$} & $\begin{array}{l}\text { 6. cognitive } \\
\text { development }\end{array}$ & 11 & 12 & 92 \\
\hline & $\begin{array}{l}\text { 7. emotional } \\
\text { development }\end{array}$ & 11 & 12 & 92 \\
\hline \multirow{3}{*}{$\begin{array}{l}\text { E. Linguistics } \\
\text { Aspect }\end{array}$} & 8. Grammar & 10 & 12 & 83 \\
\hline & 9. Spelling & 10 & 12 & 83 \\
\hline & Total skor & 93 & 108 & 86 \\
\hline
\end{tabular}

The assessment by the language validator shows that most of the linguistic aspects of the text fall into the very good and valid category based on the eligibility criteria table for teaching materials. The aspect that still needs to be refined is the aspect of sentence effectiveness. The texts in the book are suitable for use even though they have to make minor revisions. 
Table 2 Product Feasibility Assessment from Student Small Group Test Results

\begin{tabular}{|c|c|c|c|c|c|}
\hline & Indicators & $\begin{array}{l}\text { Total Score } \\
\quad \text { for } 20 \\
\text { respondents }\end{array}$ & $\begin{array}{l}\text { Maximum } \\
\text { Score for } \\
20 \\
\text { Respondents }\end{array}$ & $\%$ & Category \\
\hline \multirow[t]{6}{*}{$\begin{array}{l}\text { A. } \\
\text { Attractiveness }\end{array}$} & $\begin{array}{l}\text { 1. The appearance of this } \\
\text { reading book is interesting }\end{array}$ & 56 & 80 & 70 & $\begin{array}{l}\text { Eligible with } \\
\text { the title Good }\end{array}$ \\
\hline & $\begin{array}{l}\text { 2. This reading material } \\
\text { makes me more excited } \\
\text { about reading English } \\
\text { texts. }\end{array}$ & 59 & 80 & 74 & $\begin{array}{l}\text { Eligible with } \\
\text { the title Good }\end{array}$ \\
\hline & $\begin{array}{l}\text { 3. Using this book can } \\
\text { make reading less boring. }\end{array}$ & 56 & 80 & 70 & $\begin{array}{l}\text { Eligible with } \\
\text { the title Good }\end{array}$ \\
\hline & $\begin{array}{l}\text { 4. This reading book } \\
\text { supports me in improving } \\
\text { my reading skills, } \\
\text { especially increasing } \\
\text { vocabulary. }\end{array}$ & 59 & 80 & 74 & $\begin{array}{l}\text { Eligible with } \\
\text { the title Good }\end{array}$ \\
\hline & $\begin{array}{l}\text { 5. My attitude about learning } \\
\text { is changed after reading this } \\
\text { book }\end{array}$ & 68 & 80 & 85 & $\begin{array}{l}\text { Eligible with } \\
\text { the title Good }\end{array}$ \\
\hline & $\begin{array}{l}\text { 6. The illustrations in this } \\
\text { book motivated me to read } \\
\text { the text. }\end{array}$ & 65 & 80 & 81 & $\begin{array}{l}\text { Eligible with } \\
\text { the title Good }\end{array}$ \\
\hline \multirow[t]{6}{*}{ B. Content } & $\begin{array}{l}\text { 7. The contents of this } \\
\text { reading book are related to } \\
\text { everyday life. }\end{array}$ & 62 & 80 & 78 & $\begin{array}{l}\text { Eligible with } \\
\text { the title Good }\end{array}$ \\
\hline & $\begin{array}{l}\text { 8. the story in this book is } \\
\text { easy to understand. }\end{array}$ & 61 & 80 & 77 & $\begin{array}{l}\text { Eligible with } \\
\text { the title Good }\end{array}$ \\
\hline & $\begin{array}{l}\text { 9. I found the real meaning } \\
\text { of life from the stories in } \\
\text { this book. }\end{array}$ & 67 & 80 & 84 & $\begin{array}{l}\text { Eligible with } \\
\text { the title Good }\end{array}$ \\
\hline & $\begin{array}{l}\text { 10. The stories in this book } \\
\text { encourage me to find the } \\
\text { keys to success in life. }\end{array}$ & 68 & 80 & 85 & $\begin{array}{l}\text { Eligible with } \\
\text { the title Good }\end{array}$ \\
\hline & $\begin{array}{l}\text { 11. This reading book } \\
\text { encourages me to write } \\
\text { down what I understand } \\
\text { about myself in the "Post } \\
\text { Reading Activity" column. }\end{array}$ & 56 & 80 & 70 & $\begin{array}{l}\text { Eligible with } \\
\text { the title Good }\end{array}$ \\
\hline & $\begin{array}{l}\text { 12. This book contains } \\
\text { questions that can test how } \\
\text { far I recognize the } \\
\text { strengths of myself / } \\
\text { positive values in myself. }\end{array}$ & 63 & 80 & 79 & $\begin{array}{l}\text { Eligible with } \\
\text { the title Good }\end{array}$ \\
\hline
\end{tabular}




\begin{tabular}{llcccc}
\hline & Indicators & $\begin{array}{c}\text { Total Score } \\
\text { for 20 } \\
\text { respondents }\end{array}$ & $\begin{array}{c}\text { Maximum } \\
\text { Score for } \\
\text { 20 } \\
\text { Respondents }\end{array}$ & Category \\
\hline C. Language & $\begin{array}{l}\text { 13. The sentences and } \\
\text { paragraphs used in this } \\
\text { book are clear and easy to } \\
\text { understand. }\end{array}$ & 60 & 80 & 75 & $\begin{array}{l}\text { Eligible with } \\
\text { the title Good }\end{array}$ \\
$\begin{array}{l}\text { 14. The language used in } \\
\text { this reading book is simple } \\
\text { and easy to understand. }\end{array}$ & 54 & 80 & 68 & $\begin{array}{l}\text { Eligible with } \\
\text { the title Good }\end{array}$ \\
$\begin{array}{l}\text { 15. The letters used are } \\
\text { simple and easy to read. }\end{array}$ & 59 & 80 & 74 & $\begin{array}{l}\text { Eligible with } \\
\text { the title Good }\end{array}$ \\
\hline
\end{tabular}

Based on Table 2 the assessment of each item of the student response questionnaire shows the feasible category. The statement items that get the category of "eligible with the very good predicate", namely the influence of the contents of the reading book on student attitudes and future learning, In this reading book there are several sections for me to find the concept of the real meaning of life, Presentation of the material in this reading book encourages me to interpret the key to success in life. These three points show how the content of the reading has a positive influence on students' emotions. Another point that gets another very good category is the illustration in the book about the character in question. While the linguistic aspects such as words or sentences in the reading material reflect that the difficulty level of this reading is not easy.

\section{CONCLUSION}

Reading biographies of famous people in the local area is a prototype of a reading text that has latent benefits $\backslash$ that can promote positive educational values for EFL learners. through questions that are given after reading. Further research is encouraged to test this prototype to a bigger population to measure the effectiveness of this genre in promoting positive educational values. Also, the inputs from reading teachers who will use the book need to be under consideration in the process of refining this book in the future.

\section{REFERENCES}

Agung, A. S. N. (2019). Current Challenges in Teaching English in Least-developed Region in Indonesia. SOSHUM: Jurnal Sosial Dan Humaniora, 9(3), 266-271. https://doi.org/10.31940/soshum.v9i3.1317

Allen, M. (2017). Designing Online Asynchronous Information Literacy Instruction Using the ADDIE Model. In Distributed Learning: Pedagogy and Technology in Online Information Literacy Instruction. Elsevier Ltd. https://doi.org/10.1016/B978-0-08-100598-9.00004-0 
Brown, H. D. (2007). Teaching by principles: An interactive approach to language pedagogy (3rd ed.). (3rd ed.). Pearson Education.

Casey, L. (2013). Stress and wellbeing in Australia survey 2013.

Chun, E., Choi, S., \& Kim, J. (2012). The effect of extensive reading and paired-associate learning on long-term vocabulary retention: An event-related potential study. Neuroscience Letters, 521(2), 125-129. https://doi.org/10.1016/j.neulet.2012.05.069

Csikszentmihalyi, M. (1990). Flow: The psychology of optimal performance. (1990). . : Cambridge University Press.

Dewaele, J.-M., \& MacIntyre, P. D. (2014). The two faces of Janus? Anxiety and enjoyment in the foreign language classroom. Studies in Second Language Learning and Teaching, 4(2), 237274. https://doi.org/10.14746/ssllt.2014.4.2.5

Ferdila, R. (2014). the Use of Extensive Reading in Teaching Reading. Journal of English and Education, 2014(2), 68-80.

Foundation, E. reading. (2011). Guide to Extensive Reading.

Green, C. (2020). Extensive reading and viewing as input for academic vocabulary: A large-scale vocabulary profile coverage study of students' reading and writing across multiple secondary school subjects. Lingua, 239. https://doi.org/10.1016/j.lingua.2020.102838

Guo, S. cing. (2012). Using authentic materials for extensive reading to promote English proficiency. English Language Teaching, 5(8), 196-206. https://doi.org/10.5539/elt.v5n8p196

Horwitz, E. K., Horwitz, M. B., \& Cope, J. (1986). Foreign Language Classroom Anxiety. The Modern Language Journal, 70(2), 125-132. https://doi.org/10.1111/j.15404781.1986.tb05256.x

Jacobs, G. M., \& Renandya, W. A. (2014). Jacobs and Renandya, Making extensive reading even more student centered Making Extensive Reading Even More Student Centered.

Kift, S. (2009). A transition pedagogy : the First Year Experience Curriculum Design Symposium 2009. HERDSA News, 31(1), 1/3-4.

Kirin, W. (2010). Effects of extensive reading on students' writing ability in an EFL class. Journal of Asia TEFL, 7(1), 285-308.

McLean, S., \& Rouault, G. (2017). The effectiveness and efficiency of extensive reading at developing reading rates. System, 70, 92-106. https://doi.org/10.1016/j.system.2017.09.003

Mermelstein, A. D. (2014). Improving EFL Learners' Reading Levels through Extensive Reading. Reading Matrix: An International Online Journal, 14(2), 227-242.

Mumary Songbatumis, A. (2017). Challenges in Teaching English Faced by English Teachers at MTsN Taliwang, Indonesia. Journal of Foreign Languange Teaching and Learning, 2(2). https://doi.org/10.18196/ftl.2223

Muriati, S. (2014). Pengembangan Bahan Ajar Biologi Sel Pada Program Studi Pendidikan Biologi Uin Alauddin Makassar. Florea: Jurnal Biologi Dan Pembelajarannya, 1(2). https://doi.org/10.25273/florea.v1i2.383 
Oatley, K. (1995). A taxonomy of the emotions of literary response and a theory of identification in fictional narrative. Poetics, 23(1-2), 53-74. https://doi.org/10.1016/0304-422X(94)P4296$\mathrm{S}$

Palmieri, C. (2017). Belonging, idealized self and wellbeing. Australian Review of Applied Linguistics, 40(2), 176-193. https://doi.org/10.1075/aral.40.2.06pal

Rizki, M., \& Listiara, A. (2015). Penyesuaian Diri dan School Well-Being pada Mahasiswa. Seminar Psikologi \& Kemanusiaan, 978-979.

Ro, E. (2013). A Case Study of Extensive Reading with an Unmotivated L2 Reader. Reading in a Foreign Language, 25(2), 213-233.

Ro, E. (2016). Exploring teachers' practices and students' perceptions of the extensive reading approach in EAP reading classes. Journal of English for Academic Purposes, 22, 32-41. https://doi.org/10.1016/j.jeap.2016.01.006

Ro, E., \& Chen, C. A. (2014). Pleasure reading behavior and attitude of non-academic ESL students : A replication study. Reading in a Foreign Language, 26(1), 49-72.

Song, M. (2016). The Impact of Extensive Reading on EFL Primary School Students' Vocabulary Acquisition and Reading Comprehension. 1983.

Stallman, H. M. (2010). Psychological distress in university students: A comparison with general population data. Australian Psychologist, 45(4), 249-257. https://doi.org/10.1080/00050067.2010.482109

Wojtowicz, B. (2017). Using Extensive Reading Oral Reports to Enhance Spoken Fluency. Language Education in Asia, 8(1), 101-121. https://doi.org/10.5746/leia/17/v8/i1/a07/wojtowicz

Yamashita, J. (2008). Extensive reading and development of different aspects of L2 proficiency. System, 36(4), 661-672. https://doi.org/10.1016/j.system.2008.04.003

Yamashita, J. (2013). Effects of extensive reading on reading attitudes in a foreign language. Reading in a Foreign Language, 25(2), 248-263.

Yoshizawa, K., Takase, A., \& Otsuki, K. (2002). L2 Reading Proficiency Improvement and Reading Behaviors among Different Levels of Readers: Extensive Reading in an EFL Context. 